\title{
Åpent nummer om surrogati, bioetikk, forskningsetikk og minoriteter
}

\section{Leder}

\section{May Thorseth, Siri Granum Carson og Charles Ess}

Dette nummeret av Etikk i praksis - Nordic Journal of Applied Ethics er kommet i stand i stafettpinneskiftet mellom avtroppende og påtroppende redaksjon. Vi byr på bidrag fra et variert utsnitt av det mangfoldige forskningsfeltet som omfattes av anvendt etikk. Tematisk er det bredde i utvalget, men felles for alle bidragene er at de drøfter svært relevante tema som også er til stede i offentlige medier.

I den første artikkelen - «Bør man tillate at norske statsborgere benytter seg av surrogati i India?» - griper Annelin Haukeland, Liv Cathrine Heggebø og Kristine Bærøe fatt i en problemstilling som har utløst mange kontroverser i offentlig debatt. Muligheten av surrogati tilføyer nye elementer i mangeårige diskusjoner om kunstig befruktning, sæd- og egg-donasjon, anonymitet og foreldreskap, blant annet juridiske spørsmål knyttet til krav og rettigheter - både beskyttelse i form av anonymitet for givere, men også barnets rett til å fa vite hvem donoren er. Forfatterne reiser problemstillingene innenfor en bestemt kontekst, nemlig surrogatiavtaler mellom norske statsborgere og indiske surrogatmødre. Dermed problematiseres også muligheten av å omgå regelverket ved å gå til andre land dersom en teknologi ikke er anerkjent her hjemme. Ytterligere en dimensjon er naturligvis også rettigheter for homofile par vis-à-vis heterofile. Forfatterne berører noen av disse spørsmålene. De tar utgangspunkt i Beauchamp og Childress' fire prima facie rettigheter: autonomi, velgjørenhet, ikkeskade og rettferdighet, og forankrer slik de nye problemstillingene i velkjente bioetiske prinsipper. Basert på denne metodiske tilnærmingen argumenterer de for at surrogati bør tillates, under forutsetning av at praksisen underlegges omfattende reguleringer.

Neste artikkel - «Kristen bioetikk på defensiven» - handler også om bioetikk, men med et annet utgangspunkt enn foregående bidrag. Utgangspunktet er ikke en bestemt praksis i stedet griper Morten Magelssen her tak i en synkende innflytelse for kristen bioetikk. Denne utviklingen tilskrives i hovedsak sekulariseringen av samfunnet. En alvorlig konsekvens er at religiøs argumentasjon avvises uten at argumentene blir gjenstand for kritisk debatt. Forfatteren søker å vise at kristen bioetikk taper i det offentlige ordskiftet pga. avvisning av at kristne argumenter kan være rasjonelle. Rammen for diskusjonen er bl.a. liberaliseringen av (det norske) samfunnet, både i lys av liberaliseringen av lovverket, men også med referanse til liberal politisk filosofi generelt. Et hovedanliggende for forfatteren er at ideologiske og filosofiske trender vinner terreng i det offentlige ordskiftet, på bekostning av klassisk kristen bioetikk. Forfatteren peker på det uheldige i at debatten dermed ikke styres av rasjonelle argumenter i tilstrekkelig grad fordi viktige (kristne) argumenter ikke oppfattes som rasjonelle. Samtidig som artikkelen er et forsvar for klassisk kristen bioetikk, gir den 
primært uttrykk for en grunnleggende bekymring for at den offentlige debatten blir unyansert fordi viktige argumenter ikke kommer til sin rett.

I den tredje artikkelen - «Informeret samtykke i kliniske forsøg: teknikaliteter, tillid og tætte relationer» - undersøker Sarah Wadmann betydningen av deltakerinformasjon ved kroniske pasienters beslutning om å delta i medisinske forskningsforsøk. Et feltarbeid på fire danske forskningsklinikker danner bakgrunn for hennes argumenter. Disse går ut på at beslutninger om å delta i kliniske fors $ø \mathrm{k}$ for mange kroniske pasienter handler om å opprettholde en nær relasjon til forskningspersonalet, og i mindre grad om selve forsøket. Denne pasientgruppen orienterer seg altså ikke etter deltakerinformasjon, men ut fra tillitsrelasjoner. Forfatteren peker på viktige forskningsetiske utfordringer når det gjelder å ivareta autonomi i medisinsk forskning.

Nest siste bidrag - «Etikk på kollisjonskurs - når forvaltningsetikk og forskningsetikk møtes» - drøfter et annet aspekt ved forskningsetikk. Her tar Jill Beth Otterlei og Berit Skorstad utgangspunkt i det de identifiserer som ulike «etos» $i$ henholdsvis forvaltning og forskning innen akademia, og de viser til ulike og til dels motstridende etiske retningslinjer innenfor de to kontekstene, og drøfter hvorvidt dette svekker legitimiteten i akademia. Grunnlaget for analysen er dokumentene «Forskningsetiske retningslinjer for samfunnsvitenskap, humaniora, juss og teologi» (NESH 2006) og «Etiske retningslinjer for statstjenesten» (Moderniseringsdepartementet 2005, Revidert i Fornyings-, administrasjons- og kirkedepartementet 26.04.12). I et komparativt perspektiv diskuterer forfatterne bl.a. en slående ulikhet $i$ at frihet framheves $i$ forskningen, mens lojalitet og lydighet framheves i forvaltningen. Selv om frihet og lojalitet ikke nødvendigvis står imot hverandre, vil det likevel oppstå en motsetning der lojalitet (innen forvaltningen) fortolkes som lydighet. Forfatterne er opptatt av at denne mulige konflikten oppstår ved at også forskningen er underlagt forvaltningens etiske retningslinjer.

I den siste artikkelen - «Multiculturalism and legal autonomy for cultural minorities»spør Morten Ebbe Juul Nielsen hvorvidt multikulturalisme bør innebære juridisk autonomi for kulturelle minoriteter. Det ville i så fall innebære å gå utover bestemte særordninger som fritak og spesiell beskyttelse for minoriteter. Juridisk autonomi forstås her som særskilt jurisdiksjon for minoriteter, med henvisning til multikulturalisme-argumenter. Forholdet mellom borgere og politisk autoritet settes i et kritisk lys, der forfatteren kritiserer en monistisk forestilling som er utbredt både blant folk flest og blant fagfolk, uttrykt som én borger, én lov. Forfatteren introduserer begrepet «multilegalisme» for en alternativ posisjon. Det innebærer eksempelvis at kulturelle minoriteter tilkjennes juridisk makt til å forhandle og ta beslutninger, til forskjell fra bare tilrettelegging i form av unntak, privilegier og spesielle rettigheter på generelt grunnlag. Med utgangspunkt $i$ et normativt forsvar for multikulturalisme forstått som «multilegalisme» identifiserer forfatteren også ulike problemer og mulige innvendinger mot denne posisjonen. Mens noen av innvendingene er rent juridiske eller økonomiske, er de følgende muligens mest interessante i et anvendt etisk perspektiv: Multilegalisme er uforenlig med universell solidaritet og likhet; multilegalisme er uforenlig med noen personers rettmessige rettigheter; og multilegalisme fører til urettmessig kulturell essensialisme. Med dette inviteres leseren til en diskusjon om hvorvidt multilegalisme likevel har (normative) fortrinn framfor en mer tradisjonell forståelse av multikulturalismen.

Vi ønsker leserne velkomne til et mangfoldig nummer av tidsskriftet Etikk i praksis. 